\title{
Conflicts Around Elder Care in Mass Media: A Case Study of a Swedish TV-Documentary and the Reactions to it in Public Discourse
}

\author{
Magnus Nilsson \\ Linköping University - magnus.nilsson@liu.se
}

\begin{abstract}
Public opinion regarding the organization of welfare and elder care are issues which have mainly been studied as expressions of individual attitudes or conflicting ideologies. By contrast, and departing from an understanding of the importance of context and societal rhetoric, this study explores a media event in the form of a Swedish TV documentary about problems in elder care and the reactions to it that were published in printed news media. The study departs from a discursive psychological perspective

regard to how elder care should be organized, and which conflicts are articulated in the different articles and opinion pieces that were published during the month following the broadcast.

The study also shows how elder care is not a singular issue, but always interconnected with issues such as citizenship, identity, migration, and the legitimacy of the political and legal system. It was found that right to formal care for older people to a large extent was articulated as a right by virtue of citizenship.
\end{abstract} and focuses on what is taken for granted with

Keywords: Elder care, citizenship, mass media, discourse analysis.

\section{Conflitos em Torno da Assistência a Idosos nos Meios de Comunicação Social: Um Estudo de Caso de um Documentário Televisivo Sueco e as Reações ao Mesmo no Discurso Público}

\section{Resumo}

A opinião pública relativamente à organização do bem-estar e dos cuidados a idosos são questões que têm sido estudadas principalmente como expressões de atitudes individuais ou ideologias conflituosas. Em contraste, e partindo de uma compreensão da importância do contexto e da retórica social, este estudo explora um evento mediático sob a forma de um documentário televisivo sueco sobre problemas na assistência ao idoso e as reações a ele que foram publicadas nos meios noticiosos impressos. O estudo parte de uma perspetiva psicológica discursiva e concentra-se no que é tido como garantido no que diz 
Conflicts Around EIder Care in Mass Media: A Case Study of a Swedish TV-Documentary and the Reactions to it in Public Discourse

respeito à forma como os cuidados aos idosos devem ser organizados, e que conflitos são articulados nos diferentes artigos e pareceres que foram publicados durante o mês seguinte à emissão.

O estudo também mostra como a assistência a idosos não é uma questão singular, mas sempre interligada com questões como cidadania, identidade, migração, e a legitimidade do sistema político e legal. Constatou-se que o direito a cuidados formais para pessoas idosas foi em grande medida articulado como um direito em virtude da cidadania.

Palavras-chave: Cuidados ao idoso, cidadania, meios de comunicação de massas, análise do discurso.

\section{INTRODUCTION}

Sweden is a Nordic welfare state with comparatively extensive welfare arrangements for older people (Chung, Hrast, \& Rakar, 2018). In Sweden, health care and social services are primarily, but not exclusively, financed through taxes and guaranteed by law for all citizens through the Social Services Act (2001). Until the early 1990s, both health care and social services were provided almost exclusively by public sector providers. Since then, however, there have been substantial changes to the organization of the Swedish welfare state. Notably, the welfare sector has gone through a marketization with an increased emphasis on private providers and market solutions. A market logic has been introduced, and official discourse has come to emphasize the role of the consumer over that of the citizen (Blomqvist, 2004; Meagher \& Szebehely, 2013; Nilsson, Jönson, Carlstedt, \& Harnett, 2018; see also Clarke \& Newman, 1997).

In parallel to this development, there has been a retrenchment of the welfare state in general, and increasingly fewer people now have access to the elder care system. There has been a reduction in places at nursing homes, and the threshold for admission has crept upwards. The share of people above the age of 80 residing in nursing homes decreased from 20 percent in 2001 to 13 percent in 2013 (Socialstyrelsen, 2016). The residents of nursing homes have extensive care needs and the majority have dementia (National Board of Health and Welfare, 2013). The median age for moving into a nursing home is 86 years (National Board of Health and Welfare, 2016). Even though the next of kin - apart from a spouse - do not have a legal obligation to care for older relatives, there is growing pressure on them to do so as the welfare 
system is pulled back. The marketization of welfare services has not been without conflict, and there have been frequent protests.

Among scholars there is a fear that the retrenchment of welfare services and the increased pressures on the individual, together with a changing demography and a challenged economic situation, may increase competition for resources among groups in society (Chung et al., 2018). Social problems risk becoming even more individualized (van Oorschot, 2006). It has also been suggested that this may strengthen arguments for even more welfare cutbacks and increased pressure on families and civil society, as well as arguments for more individualized market solutions as the public systems fail to live up to people's expectations. In Swedish public opinion, support for the marketization of welfare services has been weak. Instead, as Svallfors (2011) has shown, there has been strong and stable support for tax-funded, publicly provided welfare services. However, trust in the performance of the welfare system - including elder care - has decreased (see also Holmberg \& Weissbilder, 2018).

Public opinion and conflicting ideas about the organization of welfare and elder care are issues which have mainly been studied through questionnaires, as studies of individual attitudes and opinions. By contrast, and departing from an understanding of the importance of context and societal rhetoric, this study is designed as a case study (Yin, 2003; Baxter \& Jack, 2008) that explores a media event in the form of a Swedish TV documentary and reactions to this documentary published in printed news media. The aim of this approach is to be able to be attentive to the significance of the context of utterances and how these utterances relate to each other as positions regarding elder care are developed in relation to established societal narratives. The documentary was produced by the Swedish public broadcasting company Sveriges Television (SVT), and depicted the plight of two women as they struggled to care for their loved ones and how formal elder care failed them. The documentary was widely discussed in the mass media during the following weeks. The documentary and the ensuing reactions in the mass media provide an opportunity to study the rhetorical landscape of public discourse concerning the role of society and the individual in organizing care for older people. In order to study how different positions and arguments are played out the main focus of the analysis is on the reactions that were published as reactions to the documentary.

This study's specific focus on the rhetorical landscape in the mass media is based on the fact that the mass media is a central part of contemporary society and, as Chamberlain and Hodgetts (2008, p. 1111) argue, "plays a role in setting, sustaining 
Conflicts Around EIder Care in Mass Media: A Case Study of a Swedish TV-Documentary and the Reactions to it in Public Discourse

and undermining political structures and social policies". Even in today's fragmented media landscape, the national mass media provides shared resources for understanding society, how it functions, and which issues are relevant and have a status as serious and problematic issues, as well as how people should relate to one another (Westlund \& Weibull, 2013; Chamberlain \& Hodgetts, 2008). Society and politics have become 'mediatized', that is, society has become imbued with the presence of the media, and part of the performance of institutions is now measured by how they are represented in the mass media (Marcinkowski, 2014). A documentary such as the one used here taps into established narratives in order to tell a story, while also functioning as a foundation for the further development of narratives of society, community and justice. In relation to this, the aim of the paper is to analyse 1) what is taken for granted with regard to how elder care should be organized in Sweden, and 2) which conflicts are articulated in the different articles and opinion pieces that were published during the month following the broadcast.

\section{FROM WELFARE ATTITUDES TO THE RHETORICAL LANDSCAPE OF THE MASS MEDIA}

There are two main approaches to studying public opinion on welfare arrangements for older people. The approach that is most commonly referred to is the selfinterest perspective, which starts from the hypothesis that support for welfare arrangements is based on the idea that people support programmes they themselves benefit from, in the short or the long term, directly or indirectly. For example, women's stronger support for public provision of elder care is often explained as an outcome of self-interest, since a lack of support from formal elder care will likely increase the care burden on them. Self-interest is also said to increase the risk of intergenerational conflict, as people are assumed to look out for themselves above others, even though there is a lack of studies confirming this empirically (Prinzen, 2014; Daatland, Veenstra, \& Herlofson, 2012).

The second approach focuses on the importance of norms and values for the support of different welfare arrangements. Here, the foundation for opinions and attitudes towards welfare and societal support for different groups is the socialization into the way that society is organized. This approach is based on a view that normative ideas of reciprocity, justice and obligations influence the way people understand 
their rights and responsibilities as members of a political community (i.e. 'society'), and that there is - or should be - a correspondence between these sentiments and the rules and economic organization of welfare (Kohli, 1991; Svallfors, 2008; Mau, 2004; Minkler \& Cole, 1992). According to Bode (2007, p. 203), this perspective on the relationships between welfare institutions and regulations implies that "institutions of the welfare state must (at least partially) be seen as an expression of moral rationales". The working of the institutions of society, and especially welfare institutions, is thus cast in a moral light. This implies, as shown for example by van Oorschot (2006), that support for welfare arrangements is influenced by ideology and how one sees the responsibility of the individual, the state and other institutions in society, and their respective roles.

These two approaches are unified in that they aim to tap into the thinking of the individual and treat the positions of individuals as rather stable across contexts. As a complement to this, the present study focuses on the rhetorical landscape of public discourse as a field that is part of the shaping of attitudes and policies. In order to describe the approach adopted in this paper, I will use the notion of deservingness as an example. Research has shown that the notion of deservingness is central to the understanding of how people relate to, support or reject welfare state support for different groups (van Oorschot, 2000; Will, 1993; Jönson \& Nilsson, 2007; Slothuus, 2007; Crepaz, 2008; Petersen, Slothuus, Stubager; \& Togeby, 2011). Van Oorschot (2000, p.36) identified five criteria that organize the perception of deservingness. He found that a person is seen as more deserving if he or she is perceived not to be responsible for his predicament. The greater the need, the more deserving one is perceived as. The more one is seen as one of 'us', the more deserving one is of help and assistance compared to someone who is perceived as an outsider. The more grateful or compliant one is, the more deserving. Lastly, deservingness is based on the degree to which one is perceived to have contributed to society. For example, according to van Oorschot (2000), someone who has worked and paid taxes is seen as more deserving compared to a person who has made their living from crime.

This study departs from the position that how deservingness is associated with certain social characteristics or groups, such as older people, depends on how their situation and characteristics are framed in discourse. This may vary from context to context and over time. Categories such as 'older people' or 'pensioners' are themselves the result of processes of social construction. Their meanings and values change across contexts, and who is included in these categories is often defined by the context of 
Conflicts Around EIder Care in Mass Media: A Case Study of a Swedish TV-Documentary and the Reactions to it in Public Discourse

articulation. One example that highlights this is the category 'older immigrants', who are sometimes - but not always - included in the general concept of 'older people'. Van Oorschot (2006) showed that immigrants were not as easily seen as deserving, as they are not seen as one of 'us'. However, the degree to which immigrants are seen as 'others' varies between groups of immigrants. It also depends on the rhetoric in society, for example the relative success in recent years of the political tactics of rightwing populist movements and parties of branding Muslims as 'criminals', 'terrorists' and so on. Hence, how and why particular categories fit the criteria of 'deserving' is a matter of active articulation in relation to the understanding of a 'we' and 'society' as a totality (cf. Nilsson, 2017). Thus, as Will (1993) indicates, deservingness is dependent on the way that claims are embedded in a narrative context. A study by Chung et al. (2018) on how people reason and argue regarding the welfare of older people in different European countries also emphasizes the very contextual nature of these arguments, and how they are related to the political discourse as well as the specific welfare regime. So instead of aiming to study the attitudes of individuals, this paper focuses on what I call the rhetorical landscape and the narratives of elder care in public discourse.

\section{DATA AND ANALYSIS}

The decision to study a TV documentary and subsequent reactions to it in the mass media is treated as a qualitative case study. A qualitative case study is characterized by the fact that it provides an opportunity to study phenomena as they unfold through different interrelated practices. This is also why the focus of the analysis is on the reactions to the documentary that were published in news media. A case study is, according to Yin (2003), relevant when the focus is on questions of 'how' and 'why', if one is unwilling or unable to manipulate or intervene in the process that is studied, when contextual aspects are relevant to the issue, and when the context itself plays a part in what is articulated (see also Baxter \& Jack, 2008).

The relevance of the data is based on two assumptions. First, the analysis proceeds from the assumption that the TV documentary was created using established narratives of elder care in Sweden. Second, the documentary makes claims regarding the problems and solutions of elder care in Sweden. However, it does not dictate the reactions or how it will be used by other actors in public discourse, or by people in 
general. The documentary and its narrative are used in different ways in the newspaper articles. These include reporting on the documentary, accusations against politicians who are seen as responsible, suggestions for improvements, and so on. A range of meaning-making and claims-making tasks are carried out with reference to the documentary, and the reactions can show taken-for-granted assumptions about both what is right, what is possible, and how society is understood to work. The documentary is thus treated both as a statement that needs to be described and analysed in itself, and as an event that gives rise to reactions in the form of other mass media texts. The documentary can be used in a variety of ways by different media actors, but provides an anchoring point for the articulation of meaning. The interplay, or intertextuality, between the documentary and subsequent media items highlights cultural resources and taken-for-granted meanings in public discourse.

News items in the form of articles, opinion pieces and letters to the editor published in Swedish newspapers were collected using the database Retreiver Mediearkivet by the author. The database collects articles from all major newspapers and magazines, as well as smaller, more regional publications from across Sweden. A search of the database was carried out using the title of the documentary, Hem till varje pris (Home at any cost), as a search term. The dates for the search were set from the day the documentary was aired (16 January 2016) until one month later. In total, the documentary was mentioned in 73 newspapers across Sweden. However, the majority of those were short listings for the documentary in the TV schedules. Twenty newspapers and news outlets published articles relating to the documentary. The public broadcasting company SVT also published several articles on both its national website and its regional pages. Most of the newspapers represented in the data are local newspapers. Only one of the newspapers has national coverage. One of the magazines included in the data is a membership magazine called Veteranen (the Veteran) for one of the national pensioner's organizations. In total, 52 original pieces were published during the studied period and were all included in the study. ${ }^{1}$

The largest category of items is news articles, with 23 items. This category includes interviews with politicians. Together, opinion pieces (six items) and letters to the editor (18 items) accounted for 24 items. This shows that the documentary generated many reactions from different actors in society. The data also contains many more re-

1 Significantly more articles on elder care in general were published during the period. It is possible that some of these are related to the documentary, but since it is not mentioned by name they have not shown up among the items collected for this study. 
Conflicts Around Elder Care in Mass Media: A Case Study of a Swedish TV-Documentary and the Reactions to it in Public Discourse

actions from 'ordinary people', since both SVT and Veteranen called for their readers to send in their own experiences of elder care for publication on their websites. Each of these was counted as one item, as they were published as such. SVT published 43 individual stories and Veteranen published 13.

The data was categorized and analysed by the author. In order to refine the categorization and analysis the data was reread and re-coded several times in order to refine the analysis.

The analysis draws on the insights from discourse analysis, particularly discursive psychology, as this field has developed extensive tools for analysing language use in action and the rhetorical aspects of language use (Wheterell \& Potter, 1988; Potter, 1996). Despite its name, discursive psychology is not interested in what people 'really think' or how an analysis of language can be used to understand the psychology of language users. Instead, the focus is rather on how people construct arguments and use language in order to attend to some context-specific discursive business.

One concept that is central to this study, and that is vital to discursive psychology, is the that of interpretative repertoire (Wetherell \& Potter, 1988). Language is used constructively, and what is appropriate to the context varies, as it affects what one aims to achieve in the situation. In order to be intelligible and comprehensible, language use needs to attune to established repertoires of meaning. These are called interpretative repertoires. Interpretative repertoires of meaning are used by social actors, both in constructions of utterances and in their interpretation. Potter (1996, p.116) describes interpretative repertoires as "systematically related sets of terms, often used with stylistic and grammatical coherence, and often organized around one or more central metaphors". Here, it is also important to note that actors draw on the established terms, metaphors and narratives of certain repertoires when constructing statements. Analytically, it is the regularities in the variation and context-boundedness of language use that point to these interpretative repertoires, as they cannot be analytically constructed from a single utterance. The analytic construction of interpretative repertoires in the data can point to what is taken for granted and which themes are available for different ways of articulating the moral underpinnings of elder care. What interpretative repertoires are found is therefore always generated by the analysis and cannot be predetermined by the researcher. Interpretative repertoires are important here, as they show what is taken for granted regarding, in this case, elder care, whose responsibility care is and what the problems of elder care are seen to be, as well as what the points of contention or conflict are within public discourse. 
In line with Wetherell and Potter (1988), frequency does not define the importance or relevance of an interpretative repertoire in the analysis. Rather, the analysis focuses on mapping the interpretative repertoires that are used and the arguments that are developed with them. It should also be pointed out that this type of analysis can reveal which interpretative repertoires are represented and used by actors in the mass media, but it does not claim to show how the audience will interpret and use the texts (Chamberlain \& Hodgetts, 2008).

The next section of the paper will describe the documentary and the way it constructs the problems of elder care in Sweden. After that, the analysis will proceed to the newspaper articles.

\section{RESULTS AND ANALYSIS}

\section{"Home at any cost" - the documentary}

According to Lewis (2006, p.315), the structure of news and reporting on public issues has "the function to generate heat rather than light" and accordingly media reports on elder care generally centre on problems and deficiencies (Markström, Ljuslinder, \& Sjöström, 2011). In the mass media, there is a tendency to favour the dramatic and engaging over the mundane (Lewis, 2006), as well as reporting on abuses of power and mismanagement (cf. Jönson, 2016). This is also what characterizes the documentary.

The documentary was aired on 19 January 2016 by Swedish public broadcasting television. The documentary was 28 minutes long and titled "Home at any cost". The title of the documentary alludes to the general principle in Swedish elder care that one should continue to live in one's ordinary home for as long as possible with the help of home help and home nursing. However, the title also alludes to the more specific theme of the film; that it has become increasingly difficult to get a place in a nursing home in recent decades. This is one of the issues addressed by the documentary. The second issue is a specific policy stating that, after discharge from hospital, the person returns home and an evaluation is carried out of whether home help is enough or a place in a nursing home is needed. This is a local policy, not a national policy. In line with a general dramaturgical strategy of the mass media using individual cases as examples of wider issues (Lewis, 2006), the situations of two women are used to illustrate the issues. 
Conflicts Around Elder Care in Mass Media: A Case Study of a Swedish TV-Documentary and the Reactions to it in Public Discourse

The problem of people in need of care being sent home from hospital is personified and exemplified by the situation of Linnea. She was admitted to hospital after a stroke, but has now been discharged. She has been sent home, but still needs extensive care. It is explained that she is so weak she cannot use the home help alarm she wears on her wrist. The person who speaks for her is a friend, as she cannot speak herself. Linnea's story is told by her friend over images which first show the delivery and assembly of a hospital bed in Linnea's apartment, followed by the transport car taking her home from hospital. She is rolled out from the car on a stretcher, placed in a wheelchair and finally put to bed by the staff.

The problem of getting access to a nursing home is exemplified by the plight of Wiwi Heggblad. She is in her early 70s and takes care of her husband who suffers from dementia. During the daytime he attends a day care centre run by the municipality as part of its elder care services. As well as taking care of her husband, Wiwi also cares for her mother who has been refused a place in a nursing home and has now moved in with her. This story is told over images of Wiwi caring for her husband and her mother. She helps her husband put his clothes on and use the bathroom, and she holds her mother and helps her eat breakfast.

Wiwi also organizes a protest against the closure of her husband's day care centre. She invites politicians and ordinary citizens. The strength of the documentary is not only in the presentation of the problems, but also in the way it is edited and how sound and music are used. The criticism against the politicians is given a prominent role, while the politicians' responses are truncated by the editing and the background music is turned up as they speak. Their response to the criticism is thus made inaudible and becomes a buzz. In this way, the protest against the specific event of closing the day care centre blends into a general criticism of elder care in Sweden. The documentary frames Wiwi's plight and protest as that of the ordinary citizen against the system, and against the politicians. This shift from the particular to the universal is made possible not least by the presented narrative of the history of Swedish elder care, its high ambitions and the closure of Swedish nursing homes in recent decades. It is also made possible by the omission of certain events. Before the documentary was aired, the petition and the public protests had already made Wiwi a person of interest for the local media, and according to interviews her mother had, after being denied a place at a nursing home in her municipality of residence, applied for a place at a nursing home in a neighbouring municipality and been admitted to a nursing home there. This also points to the difference in practice between municipalities 
(Trydegård \& Thorslund, 2010; Szebehely \& Meagher, 2018), which is downplayed in the documentary. Instead, the film gives the impression of elder care in Sweden facing an ongoing and escalating crisis.

\section{Reactions in the mass media}

In this part of the paper, the interpretative repertoires used in the reactions to the documentary will be described.

In order to understand the different points of contention and how the documentary was used in public discourse, it is necessary to point out what is taken for granted in the different articles. Here, what is taken for granted functions as a foundation, or as a starting point for discourse. The problem description set out in the documentary is unchallenged in the reactions. There is also no criticism of tax funding of elder care or public responsibility for elder care, and there are no suggestions for further marketization of elder care, or that the market could provide any solution to the issues described as problems. There are no arguments for an increased familiarization of elder care or demands for financial support for family carers in the face of the perceived failure of formal elder care. In other words, there are no arguments in favour of individualized elder care solutions or statements that family carers provide the best care. Professional carers are thus treated as the most suited for elder care. When family care is brought up in the newspapers, it is as a criticism against what is seen as the failure of formal care to deliver on its promise. Elder care and the rights of older people to welfare are thus treated as an issue that belongs to public authorities. Publicly organized and tax-funded elder care is seen as a right of citizenship (cf. Svallfors, 2011). Additionally, even though politicians at both national and local levels are heavily criticized for the situation, the system of governance is treated as given and not criticized. The law that regulates elder care (Social Services Act, 2001) is, with a few exceptions, not criticized. In general, it is instead the failure to apply what is perceived as the rights granted by law that is criticized. It is from this position that accusations, suggestions and discussions ensue. 
Conflicts Around Elder Care in Mass Media: A Case Study of a Swedish TV-Documentary and the Reactions to it in Public Discourse

\section{Who is at fault? What is at fault?}

The documentary and the reactions to it largely revolve around who is at fault, what constitutes the problem, what should be done in order to prevent similar events, and attempts to downplay the depicted events as a problem. In other words, public discourse on the documentary is organized around the issue of accountability (Edwards \& Potter, 1992; Potter, 1996). The question of accountability revolves around who, or what, is responsible for the situation, and for the actors who are ascribed responsibility it is a matter of taking responsibility but also disclaiming responsibility. The issue of accountability also extends beyond the direct responsibility for elder care to the issue of the status of older people in society in general, where the situation in elder care is seen as a result of this.

There are four main interpretative repertoires in the articles, and they all revolve around the issue of accountability. The first of these, which is mainly articulated by politicians, places the morality of actions and the elder care system within the system of laws and regulations. The law is regarded as the origin of rights. Through this, it is possible to deflect the politicians' responsibility. The second interpretative repertoire is in opposition to the above. Here, the law is treated as an instrument for the realization of rights of citizenship and the right to care, which is seen as given with age. The third interpretative repertoire points instead to aspects of Swedish culture and society as the cause of the perceived failure of elder care. Here, it is argued that older people have a low social status in Sweden, and increasingly so, and that this is reflected in the quality of elder care. The fourth interpretative repertoire is central to the understanding of the rhetorical landscape, but it is not represented to such a high degree as the three above. This interpretative repertoire uses a populist logic, where immigrants are seen as favoured over older people by politicians. The term 'older people' is here partly used to signify Swedishness and being ethnically Swedish.

The interpretative repertoires are described and illustrated below.

\section{The deflection of accountability: the law as the origin of rights}

The documentary framed the failures of elder care as the result of the rules and regulations set by the municipality: the strict guidelines for a place at a nursing home and the 'home and try' policy after being discharged from hospital. The film's severe 
criticism of the lack of access to short-term nursing home places and the difficulty of getting a place at a nursing home suggested that local politicians were responsible. Politicians were thus attributed with accountability. For the politicians interviewed in relation to the documentary, the issue was with the management of accountability. A defensive interpretative repertoire is primarily used here in order to deal with accountability. This interpretative repertoire rests on stressing the legitimacy of decisions made by elected bodies and the grounding of rights in the Social Services Act (2001). Questions of morality and what is right are ascribed to these institutions instead of being attributed to individual politicians, or to the decisions of individual politicians. This is illustrated below.

The Norrköping local newspaper Folkbladet published several articles in the days after the documentary was broadcast. Here, politicians from the ruling majority and officials were made to answer to the situations described in the documentary. Below are excerpts from one of the articles in which the politician responsible for elder care issues in Norrköping Municipality is interviewed. She says:

The principle of 'home and try' is a decision that's been in effect for several years, says Eva-Britt Sjöberg. It's an agreement across the county, that applies to all municipalities in the county, not only to Norrköping.

/.../

According to Eva-Britt, Norrköping was used as an example because the documentary was produced in Norrköping. She emphasizes that Norrköping is not described as unique in the documentary.

Compared to other municipalities, we are in the middle when it comes to access to a nursing home place. (Norgren, 2016)

The politician, Eva-Britt Sjöberg, is represented as disclaiming responsibility for the policy. This is done by distancing herself from the decision, referring to the decision as having been taken several years previously. This could also be interpreted as an attempt to establish the efficacy, and hence the morality, of the policy. She is also represented as deflecting responsibility by referring to the policy as the result of a consensus among several municipalities. It is also an argument against Norrköping being any better or worse than other municipalities. This argument is developed in the second part of the extract above, where she describes Norrköping as merely metonymical in discussions on elder care in Sweden. The argument that 'we just do what 
everybody else does' is a common way of disclaiming accountability in the articles. What is alluded to above is that accountability is managed by stressing the legitimacy of the Social Services Act and that regulations follow legislation. Here, the law is treated as the origin of the right to care as well as what defines the right. This is also highlighted in another interview with a local politician, who responds to the fact that a court of appeal overturned the decision by the municipality to admit an older person to a nursing home. She says:

Something that is very important for us is to make sure that it is not more difficult to get a place at a nursing home in Norrköping than in the rest of the country, and without precedents or test cases it will be more difficult to know. (Pettersson, 2016)

The law is established here not only as the baseline where the municipality must provide care, but also as the baseline which should set the norm for admission to a nursing home. Accountability is deflected by both using and arguing for the legitimacy of the law and the courts to decide on the legal lower limit, thus equating it with the moral baseline for access to a nursing home. Questions of morality and accountability are side-lined or made irrelevant in this interpretative repertoire. This interpretative repertoire rests on the established legitimacy of the law, as well as trust in the fairness of society's institutions.

The basic feature of this interpretative repertoire relies on an articulation of the legitimacy of the law and regulations of elder care, as well as treating them as the seat of morality. The rights of the individual as a citizen are treated as being grounded in these institutions. In this case, this makes it rhetorically possible for politicians to deflect responsibility for the problems of elder care articulated in the documentary.

\section{Citizenship and age as the basis for rights}

However, the accountability of politicians is not only dealt with in interviews and articles where politicians are represented as speaking. A large proportion of the articles consist of letters to the editor and opinion pieces. One theme that runs through these is the accountability of politicians and the legitimacy of decisions they have taken. In contrast to the interpretative repertoire described above, morality and amo- 
rality are here attributed to individual politicians and to politicians as a group. The right to care and welfare is not seen as grounded in the Social Services Act, but in citizenship and as something that comes with age. To be old is to have the right to care, and the law is treated as an instrument rather than the foundation of rights. One example of this is found in a letter to the editor published the day after the documentary was aired. The main argument is that people above the age of 80 should have the right to a nursing home place without a needs assessment, but the article begins by ascribing responsibility to politicians, at both local and national levels, for the situation described in the documentary.

Municipal politicians who mismanage elder care in your municipalities ought to be ashamed. The national parliament that decides on laws that allow this mismanagement ought to be ashamed.

I felt sick when I saw SVT's documentary 'Home at any cost'. I was upset and could not understand that what was once a benevolent desire to let older people continue to live in their homes has turned into misery. (Hansson, 2016)

The "benevolent desire to let older people continue to live in their homes" refers to the ambition to give care and support to the person in need in their ordinary home for as long as possible. In contrast to the way that laws, regulations and practices tend to be treated by politicians when they are interviewed as responsible, these are articulated as the result of the desire and the agency of politicians. Instead of treating the law as the measure of what is right, it is here the individual who is the bearer of rights based on age. This is why it is also possible to, as in the letter to the editor above, demand a right for people aged 80 years and over to get access to a nursing home place without a needs-based decision from a needs assessor.

Other important aspects of this interpretative repertoire where politicians are held accountable are the simultaneous criticism of politicians and their actions, and an expressed belief in the system of governance and the ability of politicians to influence the quality of elder care. Some of the articles also include suggestions for how to change rules and regulations, as in the example above, in order to strengthen the right to care and access to a nursing home place. Politicians, both locally and nationally, are criticized as immoral, ignorant and insensitive. However, the political system - or the politicians who should be responsible - is not criticized. The criticism is that the system does not deliver what is articulated as expected, and that the existing rules are 


\section{Conflicts Around Elder Care in Mass Media: A Case Study of a Swedish TV-Documentary and the Reactions to it in Public Discourse}

not followed. The charge is that politicians need to live up to what is seen as the right of the individual in old age. This is illustrated by another letter to the editor.

But the worst thing about this dismantling [of elder care] is that our decisionmakers have cut themselves off from reality to such an extent that they have forgotten to live according to the golden rule. Anything that you want others to do for you, you shall do to them. [...]

We need a paradigm shift where our politicians and decision-makers start a process towards good elder care. Where the starting point is to see to the care needs of every individual. [...]

To have dignified final years, that gives me the possibility of different experiences and community and security without worry. We have knowledgeable home care staff. Give them the opportunity to do the good work. Build more nursing homes! (Andersson, 2016)

The basic features of this interpretative repertoire are that, in contrast to the previous interpretative repertoire, the law and regulations are treated as instruments for the realization of morality and the right to care. The right to care is treated as a function of being a member of society, a citizen, and elder care is a right by virtue of age. This makes it possible to criticize and judge decisions taken by politicians and other officials. It is a challenge to the repertoire above, where the law is instead treated as the origin of rights.

\section{Holding Swedish culture accountable}

The third interpretative repertoire concerning accountability in the articles is a self-reflective and self-critical critique of Swedish 'society' and 'culture', and how older people are treated in society. Accountability is also central here, although deficiencies in elder care are not attributed to specific decisions by politicians or the organization of elder care, but as a result of a culture where older people are not recognized as being of equal worth as other age groups. This interpretative repertoire is present in both articles that are critical of politicians as a minor element and articles where this is the main line of reasoning. One example of this is taken from a letter to the editor: 
Sweden is slowly building up age apartheid. Old people who are no longer productive have no worth anymore. (Johnson, 2016)

In the excerpt above, the lack of social worth is attributed to the notion of older people being "no longer productive" and hence being seen as not contributing to society. This is often taken as a position that is argued against, implicitly or explicitly, in texts asserting the social worth and rights of older people, both in the data for this paper and in previous research (van Oorschot, 2000; Nilsson 2008).

To illustrate this cultural critical interpretative repertoire, I will provide examples from an item where the editor-in-chief wrote a longer piece about the status of older people in society. He begins his piece as follows:

"It is a shame how we treat older people in Sweden today. Those who built the country, the prosperity, that we younger people now enjoy are being treated as something the cat dragged in, like a piece of meat that can lie and rot at home." (Kustvik, 2016)

These lines echoes existing arguments in favour of the rights of older people. As other research has shown (Jönson \& Nilsson, 2007; van Oorschot, 2000, 2006), referring to previous contributions to society ("Those who built society") is a way of legitimizing the rights of older people in the present. It is a line of reasoning that accepts the premise that social worth is based on economic productivity, but in this case sees previous contributions as a basis for social status and the right to welfare in the present. This argument is also seen in the fourth interpretative repertoire, and will be explored further in relation to that repertoire.

The article continues with the author giving examples from the life of his motherin-law, who has dementia, lives alone in her own apartment, and sometimes wanders astray. Still, he claims, she is denied a place at a nursing home by the municipality where she lives.

The problem can be found throughout Swedish society, not just with politicians and officials. We treat older people badly. In many other countries it is natural to venerate the elderly, to treat them with respect and dignity and put them in focus at family gatherings and other occasions. In Sweden, it is the young we worship. Mostly the small children, we rake, sweep and kiss the ground they 
Conflicts Around Elder Care in Mass Media: A Case Study of a Swedish TV-Documentary and the Reactions to it in Public Discourse

crawl and walk on, while the elderly should be happy to be even invited to family occasions. When later on they can't take care of themselves, they are locked into their apartments with an alarm on the door. (Kustvik, 2016)

This extract is based on two oppositions in terms of how it articulates criticism against the status of older people in Swedish society. First, the author makes a distinction between "Swedish society" and "many other countries", and argues that older people in other countries have a higher status as they are treated with "respect and dignity". This is a common trope. Second, the author also articulates a contrast between the treatment of older people and children, specifically small children. What the article above also illustrates is what Nilsson $(2008 ; 2017)$ has called including othering. This means that older people are treated as members of society as an object of care, but are excluded as actors of public discourse. The 'we' that is used here, and in other instances of including othering, articulates a community of non-old as members of the public among whom discussions are held on how older people should be treated and how to define what "respect and dignity" mean in relation to older people. The contrast between children and older people underlines this, as both these categories are generally seen as dependent on the middle-aged 'we' of rational actors.

The basic features of this interpretative repertoire rest on an understanding of social worth and status as based on being economically productive. The rights of older people as a group are seen as grounded in previous contributions to society in the form of work and paying taxes. A central conflict here is that older people are described as not being treated with due respect because of a culture that does not value them as members of society. Problems and deficiencies in elder care are hence not treated as a result of the decisions taken by politicians or attributable to certain political ideologies, but to a general cultural and societal devaluation of older people.

\section{The anti-immigrant repertoire}

A range of actors used the documentary and the narrative of the decline of elder care as a rhetorical tool to further their own agenda. What stands out here is that what on the surface may appear to be about elder care, justice and the rights of older people can be interpreted as being primarily about something else. The articles that use the documentary as a tool to legitimize claims include political opponents 
criticizing each other. An article in a local edition of a national newspaper describes their municipality as the best when it comes to elder care based on the statistics provided in the documentary. Elder care employees argue for better working conditions. Another article argues that a previously highlighted trade union corruption scandal pales in comparison with cuts in elder care, so it should no longer be talked about, and so on. In terms of content or rhetoric, these instances are not attributable to a certain interpretative repertoire or a certain theme beyond the ones described above.

As has been shown in previous research (Nilsson, 2008; 2017; Jönson \& Nilsson, 2007), discussions about elder care and the rights of older people are often intertwined with themes such as immigration and citizenship. This is often articulated by populists and right-wing extremists, both in Sweden and elsewhere in Europe. In these cases, arguments for the rights of older people largely appear more as rhetorical tools for making anti-immigrant claims. However, it is also the case that the two issues often appear side by side, where both anti-immigrant arguments and arguments for the welfare of older people are part of the same discourse. This is at the centre of the fourth interpretative repertoire. This repertoire is related to the one above, where politicians are treated as accountable, but the sharp focus on migration makes it different.

There are some rhetorical features of the texts using this repertoire that set them apart from the ones described above. It is not an established practice to describe one's political affiliation in letters to the editor when they are written by a private citizen. However, the writers of the texts detailed here often describe themselves as unpolitical citizens or as people who have never voted for the right-wing populist party the Sweden Democrats. This party is mostly concerned with arguing against immigration and especially Muslims. In this group of letters to the editor, it is more common for the author to be anonymous and use pseudonyms, as in the examples below. It is also common to refer to the authors' feelings as citizens and as individuals. They describe themselves as "sickened", "worried", "sleepless" and "afraid" as a result of the perceived elder care situation.

Ageing and belonging to the category 'older people' are articulated in this repertoire as political in themselves. There is an accentuation of the relationship between older people and the state as established through the morals of the pension system. The grounding of rights in the present by prior contributions is central here ("have built the country"). In Sweden, it is also often - but not always - an expression that characterizes older people as ethnically Swedish and white (Nilsson, 2017). Below I 


\section{Conflicts Around Elder Care in Mass Media: A Case Study of a Swedish TV-Documentary and the Reactions to it in Public Discourse}

will show how the issues of elder care and immigration have been entangled in this repertoire.

Why is there no money for elderly care, for the disabled and poor pensioners? Yes, the question is easy to answer if you dare to pull your head out of the sand and see the results from our generous immigration policy, where everyone gets benefits from the first day that we don't have ourselves. There are old people who can't afford their medicines or to go to the dentist. And there aren't any nursing home places, since 32,000 places have disappeared over the years. [...] I'm almost ashamed to call myself Swedish. (Vakna upp och skäms [Pseudonym, meaning "wake up and be ashamed"], 2016)

Foolish as I am, I thought that taxes should go towards a secure old age, but it looks bad on that front. Instead, they seem to go towards an oversized refugee policy, high wages and benefits, and expensive trips and parties for politicians. Is that right? I hope the TV programme is rerun! Recommended! ( $₫$ xå trött [Pseudonym, meaning "also tired"], 2016)

As described above, this interpretative repertoire rests on a populist and anti-immigrant rhetoric. Politicians are described as willingly and knowingly favouring immigrants and refugees at the expense of older people. This interpretative repertoire uses elements that are already established in general public discourse and politics, such as the grounding of the rights of older people on previous contributions. This is, however, articulated through a populist logic that divides society into 'the people' and 'the elite'.

This can be seen here as the same arguments and claims used by the two previous interpretative repertoires. However, these are articulated and emphasized differently. The self-critical, cultural-critical interpretative repertoire and the anti-immigrant interpretative repertoire, for example, are both based on the argument that previous contributions to society in the form of work and paying taxes mean older people deserve reverence and welfare in the present. However, the argument is used differently, with the anti-immigrant repertoire claiming that older people are denied their due rights by politicians in favour of immigrants and refugees, while this argument is not present in the cultural-critical repertoire. Just as in the second interpretative repertoire, where politicians are held accountable for the elder care situation, old age 
is seen as an issue of citizenship. Here, it is developed as an antagonistic narrative between what is described as legitimate and illegitimate members of society where immigrants are described as favoured by politicians. Elder care is not an isolated issue, appearing more as an example of how people are denied what they see as belonging to them as Swedish citizens.

\section{CONCLUSIONS AND DISCUSSION}

The use of a TV documentary and the reactions to it in the mass media as a case study have provided an opportunity to analyse and show some of the wealth of arguments, descriptions and points of contention that exist in Swedish public discourse around elder care. Even though the results of this study resonate with previous research there are limits to the generality of the results.

The focus on interpretative repertoires has made it possible to focus on and highlight the rhetorical landscape in the form of established narratives and taken-forgranted assumptions, what the problems of elder care are, and who or what is articulated as being responsible. The study shows how the issue of accountability is central to developing the arguments and the interpretative repertoires found in the reactions to the documentary. This is a highly salient result of this study, but may not be indicative of how these issues are dealt with across different contexts and political conjunctures in Sweden. The issue has not been studied through this lens before. That accountability structured the way that the responses were devised in the articles may be related to how the documentary framed the issue, and the rhetorical force of the production, it can also be due to other factors in for example the wider public discourse.

One of the main features of the analysis is that it can identify different interpretative repertoires and how each of these are linked with other issues of public concern. 'Old age' and the welfare of older people emerge not only as issues associated with generational relations, as studies in this field tend to focus on, but also as entangled with issues of morality, politics, belonging and identity, citizenship and what it means to be a member of society (cf. Bode, 2007; Nilsson, 2017). Together with other studies (for example van Oorschot 2006; Nilsson, 2017) this points to that the issue of elder care and how people relate to it should not be understood in isolation from other social and political issues. It is interconnected with other issues. Examples from this 
Conflicts Around EIder Care in Mass Media: A Case Study of a Swedish TV-Documentary and the Reactions to it in Public Discourse

study include the legitimacy of laws and regulations, and how they are seen as either the origin of rights or instruments for the realization of rights, in this case the right to care based on citizenship and being a legitimate member of society.

This is not least highlighted by the anti-immigrant interpretative repertoire, where the entanglement is to such a degree that the issue of the right to elder care and the anti-immigrant stance have become part of the same (cf. Jönson \& Nilsson, 2007). However, just as these different interpretative repertoires are part of how elder care is constituted, they should also be treated as simultaneously active ingredients in the constitution of more general discourses on society, belonging and citizenship.

One narrative that runs through the interpretative repertoires is that elder care no longer provides the level of care that it once did or that it should. An exception to this is the repertoire used by politicians in order to deflect accountability. The retrenchment of the Swedish welfare state is, in other words, a fundamental narrative that structures the rhetorical landscape on elder care. Scholars have voiced a concern that welfare retrenchment and a changing demography may strengthen arguments for the further individualization of welfare systems, as it may seem that competition among different groups is increasing (e.g. van Oorschot, 2006). The narratives that were present in the interpretative repertoires found in this study do not show this. The absence of the notion of the consumer in the totality of the data and the focus on citizenship and the rights that come with being a member of society instead point to a possible rift between how public discourse and the rhetorical landscape is organized and, on the other hand, the direction of change in the welfare system. Nevertheless, the emotionally charged references to citizenship can be seen as being in line with what Svallfors (2011) and Holmberg and Weissbilder (2018) saw as a lack of trust in the ability of the welfare system to perform and live up to what is articulated as a promise by the public.

\section{REFERENCES}

Andersson, L. (2016, January 28). Ett hem till varje pris. Hallandsposten.

Baxter, P., \& Jack, S. (2008). Qualitative case study methodology: Study design and implementation for novice researchers. The qualitative report, 13(4), 544-559. 
Blomqvist, P. (2004). The choice revolution: Privatization of Swedish welfare services in the 1990s. Social Policy \& Administration, 38(2), 139-155.

Bode, I. (2007). New moral economies of welfare: The case of domiciliary elder care in Germany, France and Britain. European Societies, vol. 9, no. 2, 201-227.

Chamberlain, K., \& Hodgetts, D. (2008). Social psychology and media: critical considerations. Social and Personality Psychology Compass, 2/3, 1109-1125.

Chung, H., Filipovic Hrast, M., \& Rakar, T. (2018). The provision of care: Whose responsibility and why? In P. Taylor-Gooby, \& B. Leruth, (eds.) Attitudes, Aspirations and Welfare. Social Policy Directions in Uncertain Times. Cham: Palgrave MacMillan.

Clarke, J., \& Newman, J. (1997). The managerial state: Power, politics and ideology in the remaking of social welfare. Sage.

Crepaz, M. M. L. (2008). Trust beyond borders: Immigration, the welfare state, and identity in modern societies. Ann Arbor, University of Michigan Press.

Daatland, S.V., Veenstra, M., \& Herlofson, K. (2012). Age and intergenerational attitudes in the family and the welfare state. Advances in Life Course Research, 17, 133-144.

Edwards, D., \& Potter, J. (1992). Discursive psychology (Vol. 8). London, Thousand Oaks, New Delhi: Sage publishing.

Hansson, R. (2016, January 21). Alla över 80 borde ha rätt till äldreboende. Sydsvenskan.

Holmberg, S., \& Weissenbilder, M. (2018). Betyg på offentlig verksamhet 2017. SOMrapport nr 2018:4. Gothenburg: SOM-Institutet.

Johnson, T. (2016, January 26). Åldersapartheid är en värre kommunalskandal. Arbetet.

Jönson, H., \& Nilsson, M. (2007). Are old people merited veterans of society? Some notes on a problematic claim. Outlines. Critical Practice Studies, 9(2), 28-43.

Jönson, H. (2016). Framing scandalous nursing home care: What is the problem? Ageing and Society, 36, 400-419. 
Conflicts Around Elder Care in Mass Media: A Case Study of a Swedish TV-Documentary and the Reactions to it in Public Discourse

Kohli, M. (1991). Retirement and the moral economy: An historical interpretation of the German case. In Meredith Minkler \& Caroll L. Estes (Eds.), Critical perspectives on aging: The political and moral economy of growing old. New York, Baywood Publishing.

Kustvik, K. (2016, January 23). Vi behandlar äldre för dåligt. Östgöta Correspondenten.

Lewis, J. (2006). News and the empowerment of citizens. European Journal of Cultural Studies. 9(3), 303-319.

Marcinkowski, F. (2014). Mediatisation of politics: Reflections on the state of the concept. Javnost - the public, 21(2), 5-22.

Markström, C., Ljuslinder, K., \& Sjöström, S. (2011). Konsensus och personifierade konflikter: problembeskrivningar av äldreomsorg i svensk dagspress. Sociologisk forskning, 5, 23.

Mau, S. (2004). The moral economy of welfare states: Britain and Germany compared (Vol. 5). Abingdon, Routledge.

Meagher, G., \& Szebehely, M. (2013). Marketisation in Nordic eldercare: A research report on legislation, oversight, extent and consequences. Department of social work, Stockholm University.

Minkler, M., \& Cole, T. R. (1992). The political and moral economy of aging: not such strange bedfellows. International Journal of Health Services, 22(1), 113-124.

Nilsson, M. (2008). Våra äldre: om konstruktioner av äldre i offentligheten (Doctoral dissertation, Linköping University Electronic Press).

Nilsson, M. (2017). Nationalism and the moral economy of ageing. In I. Loffeier, T. Moulaert, \& B. Majerus (Eds.), Framing Age: Contested knowledge in Science and Politics. Abingdon, Routledge.

Nilsson, M., Jönson, H., Carlstedt, E., \& Harnett, T. (2018). Nursing homes with lifestyle profiles-part of the marketisation of Swedish eldercare. International Journal of Care and Caring, 2(1), 49-63.

Norgren, S. (2016, January 20). “Ett exempel på en felbedömning.” Folkbladet. 
Petersen, M. B., Slothuus, R., Stubager, R., \& Togeby, L. (2011). Deservingness versus values in public opinion on welfare: The automaticity of the deservingness heuristic. European Journal of Political Research, 50(1), 24-52.

Pettersson, Tommy (2016, February 3) Äldreomsorg till varje pris. NorrköpingsMagazinet.

Potter, Jonathan (1996). Representing reality. Discourse, rhetoric and social construction. London, Thousand Oaks, New Delhi: Sage Publications.

Prinzen, Katrin (2014). Intergenerational ambivalence: new perspectives on intergenerational relationships in the German welfare state. Ageing and Society, $34,428-451$.

Slothuus, R. (2007). Framing deservingness to win support for welfare state retrenchment. Scandinavian Political Studies, 30(3), 323-344.

Social Services Act (2001). Socialtjänstlag 2001:453. http://www.riksdagen. se/sv/dokument-lagar/dokument/svensk-forfattningssamling/ socialtjanstlag-2001453_sfs-2001-453

Socialstyrelsen (National Board of Health and Welfare). (2013). Äldre -vård och omsorg den 1 oktober 2012 - Kommunala insatser enligt socialtjänstlagen samt hälso- och sjukvårdslagen.

Socialstyrelsen (National Board of Health and Welfare). (2016). Statistik om särskilt boende, https://www.socialstyrelsen.se/globalassets/sharepoint-dokument/ artikelkatalog/statistik/2016-12-5.pdf

Svallfors, S. (2008). The generational contract in Sweden: Age-specific attitudes to age-related policies. Policy \& Politics, 36(3), 381-96.

Svallfors, S. (2011). A bedrock of support? Trends in welfare state attitudes in Sweden, 1981-2010. Social Policy \& Administration, 45(7), 806-825.

Szebehely, M., \& Meagher, G. (2018). Nordic eldercare-weak universalism becoming weaker? Journal of European Social Policy, 28(3), 294-308.

Trydegård, G. B., \& Thorslund, M. (2010). One uniform welfare state or a multitude of welfare municipalities? The evolution of local variation in Swedish elder care. Social Policy \& Administration, 44(4), 495-511. 
Conflicts Around Elder Care in Mass Media: A Case Study of a Swedish TV-Documentary and the Reactions to it in Public Discourse

Vakna upp och skäms. (2016, February, 9). Inte värdig behandling efter ett långt liv. Västerbottenskuriren

van Oorschot, W. (2000). Who should get what, and why? On deservingness criteria and the conditionality of solidarity among the public. Policy and Politics. Studies in local government and its services, 28(1), 33-48.

van Oorschot, W. (2006). Making the difference in social Europe: deservingness perceptions among citizens of European welfare states. Journal of European social policy, 16(1), 23-42.

Westlund, O., \& Weibull, L. (2013). Generation, life course and news media use in Sweden 1986-2011. Northern Lights: Film \& Media Studies Yearbook, 11(1), 147173.

Wetherell, M., \& Potter, J. (1988). Discourse analysis and the identification of interpretative repertoires. In C. Antaki, (Ed.) Analysing everyday explanation: A casebook of methods, 1688183.

Will, J. A. (1993). The dimensions of poverty: Public perceptions of the deserving poor, Social Science Research, 22(3), 312-332.

Yin, R. K. (2003). Case Study Research: Design and Methods, 3rd ed., London, Thousand Oaks, New Delhi: Sage Publications.

Åxå trött. (2016, February 11). De äldres pengar går till annat. Hallandsposten. 